Muscular dystrophy research Positive move

Not content with the paradoxical increase in public donations to charities in times of recession, the Muscular Dystrophy Group of Great Britain (MDG) is aiming to raise an additional income of $£ 1.5$ million from industry over the next four years. And to coordinate the use of this money, earmarked for supporting clinical trials and work on the X-chromosome with that of their regular income, MDG have created the full-time post of research development director and filled it with an eminent scientist.

At the age of 59, Professor Arthur J. Buller takes on the new job. In his career Professor Buller has moved across the spectrum of bodies supporting UK medical research, serving as a member of the Medical Research Council (MRC) from 1975 to 1981, becoming dean of the Faculty of Medicine at Bristol University in 1976 and moving to the government's Department of Health and Social Security as Chief Scientist in 1978. Now he feels less optimistic about public sector support for research and views the drain on university funds and the cutback in government support for research as a serious threat to the dual support system. Medical charities can, he feels, ameliorate this situation.

MDG works on an annual budget of $£ 1.5-2$ million raised through 450 voluntary bodies (the Muscular Dystrophy Association of the United States has a budget in the region of $\$ 16$ million). In 1981 a total of $£ 1,321,719$ was made avail- able for research - 45 specific projects have been approved for the academic year which began in October 1981. The biggest handout will go to the group's own research laboratory in Newcastle $(£ 189,254)$. Two London hospitals will receive over $£ 100,000$ for work investigating tissue culture in dystrophic muscle and in the development and differentiation of single muscle cells.

The additional money gathered by the fund-raising committee will be diverted to what the group describes as "significant new research developments". It is hoped that $£ 1$ million will go to work on the $\mathrm{X}$-chromosome. The techniques of recombinant DNA and gene cloning are already being applied to the $\mathrm{X}$ and other chromosomes with the dual aims of developing reliable methods of prenatal diagnosis and discovering the underlying genetic defect of several incurable diseases. Such work is already funded by the MRC and the Cystic Fibrosis Trust but MDG want to make certain that efforts are specifically directed to Duchenne muscular dystrophy, a disease linked to an unknown defect of the $\mathrm{X}$-chromosome.

The other $£ 0.5$ million that MDG hope to raise from industry will be spent on clinical trials. The assessment of these is likely to be helped by the availability in a London hospital of a $£ 200,000$ nuclear magnetic resonance machine. This was purchased with the assistance of MDG and will enable muscle metabolism to be studied without taking tissue samples.

MDG is a working example of how medical charities can give invaluable support to research when public sources

\section{Musical chairs at the CEA}

The French Commissariat a l'Energie Atomique (CEA) is to be reorganized, little more than a decade after the reforms of André Giraud set the CEA on its feet again.

In Giraud's time, the problem was that the CEA had lost a major battle over the choice of power reactor for a French nuclear programme: CEA wanted the indigenous French gas-cooled system, whereas Electricité de France backed the American pressurized water reactor (PWR). Electricité de France won, and the broken CEA had to be given new confidence. Giraud achieved that, and also helped set up France's nuclear industry, now so successful, behind the PWR.

Why the need to reform again? In part, CEA has outgrown the Giraud structure. It now controls many subsidiary companies whose management needs to be rationalized. But, more importantly, the new broom of the socialist government is to sweep clean. The catchwords are decentralization and regionalism. "Some reform of the CEA would have had to take place anyway" a CEA spokesman said last week “but it's going to go further with the new government than it would have done with Giscard d'Estaing',.

M. Michel Pecqueur, CEA's administrator-general, is to announce details of the reforms this week, with the hope - if the trade unions agree - that the budget for next year should be determined under the new structure. That means things must move fast, for the budget process begins in June.

One key issue will be the role of the seven délégués, who control the key sectors of CEA (nuclear applications, reprocessing, research and so on). Some say that these Paris-based posts carry too much power, and there must be some devolution to the units that the délégués control - among them the fundamental research laboratories at Fontenay-auxRoses. However, one of the délégués last week expected their roles to remain much the same after the reform. The names of the posts might be changed, but the duties would not. Indeed, it is claimed that the reforms will not be revolutionary. No doubt that is CEA's intention.

Robert Walgate are running dry. It may also prove that charity can keep new research initiatives at home - additional funds help stem the brain drain.

Jane Wynn

\section{Ecology in the Sinai Time of change}

The final hand-over of the Sinai last week brought to an end an era of strict conservation and ecological surveying. Although there had been proposals, at the time of the Camp David talks, that the Sinai should become an "International Ecological Park for Peace", these have failed to materialize. Moreover, according to Israeli ecologists, Egyptian plans to develop the Sinai could lead to the repetition of Israeli ecological mistakes committed with the best intentions by the early settlers.

Under the Israelis, three major ecological centres had been established: a bird migration monitoring station at $\mathrm{El}$ Arish on the Mediterranean, a field studies school near the Santa Caterina Monastery, and the Ras Muhammed underwater observatory. None of these is still in operation, although a special agreement was signed ensuring the continuation of the Santa Caterina school. The unique coral habitat at Rad Muhammed has been virtually destroyed by soldiers fishing with hand-grenades.

Under Israeli control, ecological protection in the Sinai reached an almost ludicrous level, with tourists forbidden to pick up seaweed or coral from the beach for fear they might then drop it in the desert and upset the ecological balance.

The Egyptians have ambitions plans for developing the Sinai, but Israeli ecologists know all too well the ecological hazards of the pioneering spirit - citing drainage of the Huleh swamps in North Galilee, and Ben Gurion's plans for intensive development of the Negev.

Whether or not in cooperation with Israel, the Egyptians are matching Israeli developments. They are particularly interested in developing solar ponds as energy sources, and Israeli plans to replenish the Dead Sea from the Mediterranean. One Egyptian plan envisages an artificial "Dead Sea" in the Quattana depression, southwest of El Alamein. As this lies below sea level, the canal bringing in Mediterranean water could be used to generate power, while the resulting salt lake could, as in Israel, be concentrated by evaporation to form the basis of a chemical industry.

The emotional and political overtones of the return of the Sinai to Egypt make it unlikely that the Egyptians would seek Israeli advice on how best to develop the area. However, the Israeli ecologists, who have worked long hours during the past few months to make their Sinai studies as complete as possible, express themselves willing, to make their data available to the Egyptians.

Vera Rich 